\title{
AN IMPROVED MICROMETHOD FOR FRACTIONAL DETERMINATION OF VITAMIN A ALCOHOL AND ESTER AND THE CHANGES IN BOTH TYPES OF VITAMIN A IN BLOOD PLASMA, MILK AND LIVER AFTER LOADING WITH BOTH TYPES OF THE VITAMIN AND $\beta$-CAROTENE
}

\author{
AKIJI FUJITA AND KOJI KIMURA \\ Biochemical Laboratory, Kitasato Institute, Shiba-Shirokanesankocho, \\ Takanawa, Tokyo
}

(Received October 9, 1959)

For investigating vitamin A metabolism, it is necessary to determine accurately the vitamin A contents in the blood, milk and tissues, especially the liver. A method of fractional determination of the free and esterified forms of the vitamin in the blood and milk has been investigated previously in our laboratory (1), but the amount of the material required for this method was too great for practical use in conducting metabolism studies in man. A micromethod was therfore divised and thus the change in the two forms of the vitamin in the tissues following loading with the vitamin was exmined using this method.

\section{EXPERIMENTAL}

\section{Reagents and Apparatus}

Weakly Activated Alumina - After washing "alumina KK2" (Kaken) with water, it was spread out on a watch glass, placed in an electric oven at $150^{\circ}$, stirring at frequent intervals, and dried to a constant weight. Prior to use, $0.15 \mathrm{ml}$ of water was added dropwise to each $1 \mathrm{~g}$ of the alumina, mixing well by stirring with a glass rod and the whole was incubated for about an hour. This was suspended in petroleum benzine (PB) to fill an adsorption tube. Through an adsorption column $(0.75 \times 2.5 \mathrm{~cm}) 10 \mu \mathrm{g}$ of vitamin A alcohol dissolved in $1 \mathrm{ml}$ of $\mathrm{PB}$ was passed, followed by developing with $2 \mathrm{ml}$ of $\mathrm{PB}$ twice. The alumina was then pushed out of the tube, the Carr-Price reagent was added on the longitudinal section of the column. When the alumina appropriately activated was used, a blue color appeared in the central part. If not, the degree of activation was properly adjusted by adding a small amount of water or dried almina and mixing well (19).

Small Adsorption Tube-A small tube $(0.35 \times 5.0 \mathrm{~cm})$ was filled with the weakly activated alumina, prepared as above, suspended in PB to make a column, $2.5 \mathrm{~cm}$ in height. The flow rate was about 25 drops per minute. 
$1 \mathrm{~N} \mathrm{KOH}$ in 90 per cent Ethanol - 1 volume of $11 \mathrm{~N} \mathrm{KOH}$ was added to 10 volumes of ethanol.

Petroleum Benzine $(P B)$

Petroleum Ether (PE)

20 per cent Acetone in PB

Vitamin A Palmitate - It was obtained from the Japan Vitamin Oil Company. For load test it was used as a solution in olive oil.

Vitamin A Alcohol -5 per cent $\mathrm{KOH}$ in ethanol was added to vitamin A palmitate, heated and the non-saponifiable portion was used.

$\beta$-Carotene - The crystalline preparation of Hoffmann-La Roche was used. For load test, a solution in $4 \mathrm{ml}$ of olive oil was used.

Beckman Microcells and Diaphragm Attachment (3)

Beckman Spectrophotometer DU Type

All the reagents were free from peroxide.

\section{Fractional Determination of Vitamin A Alcohol and Ester}

Determination of Vitamin A in Blood Serum or Milk .... To $1 \mathrm{ml}$ of serum or milk were added $1 \mathrm{ml}$ of $1 N \mathrm{KOH}-90$ per cent ethanol and $1 \mathrm{ml}$ of $\mathrm{PE}$, the mixture was shaken well for about 5 minutes and the PE phase was taken. In the case of liver, it was ground in ethanol and was diluted with the solvent up to $3-5$ times dilution. After centrifugation, $1 \mathrm{ml}$ of the supernatant was taken, $1 \mathrm{ml}$ of $1 \mathrm{~N} \mathrm{KOH}$ and $1 \mathrm{ml}$ of $\mathrm{PE}$ were added, the whole was shaken well and treated further as described above. The aqueous phase was extracted twice with $1 \mathrm{ml}$ of $\mathrm{PE}$ each. The PE phases were collected, washed 3-4 times with water, the PE phase was then evaporated off, a small quantity of methanol was added, and the methanol was then evaporated off. $0.2 \mathrm{ml}$ of $\mathrm{PB}$ was added to the residue (in the case of liver $1 \mathrm{ml}$ was added) and $0.1 \mathrm{ml}$ was used for chromatography. After passing twice $0.2 \mathrm{ml}$ of $\mathrm{PB}$, all the vitamin ester appeared in the effluent. It was collected in a small tube quantitatively. Then, $0.2 \mathrm{ml}$ of 20 per cent acetone in $\mathrm{PB}$ was passed twice, whereby the vitamin alcohol was quantitatively appeared in the effluent, which was collected in a small test tube. The time required for chromatography was 5-6 minutes. Under this condition both vitamin A alcohol and ester were recoverd quantitatively.

Each fraction was evaporated separately. To the residue are added 0.1 $\mathrm{ml}$ of $\mathrm{CHCl}_{3}$ and $0.2 \mathrm{ml}$ of glycerol dichlorohydrin $(\mathrm{GDH})$ reagent (containing $40 \mathrm{mg} / \mathrm{ml}$ of $\mathrm{SbCl}_{3}$ and $0.01 \mathrm{ml}$ concentrated $\mathrm{HCl}$ per $\mathrm{ml}$ ). The optical density $E(1 \mathrm{~cm}, 556 \mathrm{~m} \mu)$ is determined in a Beckman microcell as described by Kimura (2).

The vitamin A content is calculated by the following formula.

$$
x=f \times E \times \frac{100}{0.5}(\mu \mathrm{g} \text { per } 100 \mathrm{ml})
$$

$f$ was found to be $3.0-3.2$, using a standard solution of vitamin A. The amount of the sample used for chromatography corresponded to $0.5 \mathrm{~g}$ in the case of serum. An appropriate weight should be used.

Determination of Vitamin A in Tissues — Vitamin A can readily be ex- 
tracted from serum and milk with PE but in the case of liver, it must be homogenized prior to extraction. Mouse liver was homogenized with ethanol and the whole was centrifuged. $5 \mathrm{ml}$ of the supernatant is withdrawn and $5 \mathrm{ml}$ of $1 N \mathrm{KOH}$ was added. After mixing well, it is extracted with $10 \mathrm{ml}$ of PE. The aqueous phase was extracted twice with $5 \mathrm{ml}$ of $\mathrm{PE}$, washed with water, evaporated to dryness, and the residue was dissolved in $1 \mathrm{ml}$ of $\mathrm{CHCl}_{3}$. The vitamin content was determined by the GDH method. Under these conditions, $5 \mu \mathrm{g}$ of vitamin A alcohol and of ester added prior to treatment was recovered practically completely (95 and 97 per cent, respectively).

\section{RESULTS}

\section{Distribution of Vitamin A Alcohol and Ester in Serum}

$1.0 \mathrm{ml}$ of human serum was used. For recovery test of vitamin A ester, vitamin A palmitate was purified by chromatography and $0.4 \mu \mathrm{g}$ of the ester was used. For the test of vitamin A alcohol, vitamin A palmitate was saponified and the unsaponifiable matter was subjected to chromatography and $0.4 \mu \mathrm{g}$ of vitamin $\mathrm{A}$ alcohol thus separated was used. The results are shown in Table $\mathrm{I}$. The recovery was fairly satisfactory. About 90 per cent of vitamin $A$ in serum was $A$ alcohol and about 10 per cent was A ester, in agreement with the finding of the previous expriment in this laboratory (1).

\section{TABLE I}

Distribution of Vitamin A Alcohol and Ester in the Sera of Healthy Men Parenthesized figures indicate the recoveries of added vitamin.

\begin{tabular}{|c|c|c|c|c|}
\hline \multirow{2}{*}{ Age } & \multirow{2}{*}{ Sex } & \multicolumn{2}{|c|}{ Vitamin A content in serum } & \multirow{2}{*}{ Alcohol/total A } \\
\hline & & Alcohol & Ester $^{a}$ & \\
\hline & & $\mu \mathrm{g} / 100 \mathrm{ml}$ & $\mu \mathrm{g} / 100 \mathrm{ml}$ & per cent \\
\hline 28 & $\mathrm{~m}$ & $45.2(94.6)$ & $6.54(91.2)$ & 87.5 \\
\hline 31 & $\mathrm{~m}$ & $43.7(92.5)$ & $1.98(97.5)$ & 91.5 \\
\hline 46 & $\mathrm{f}$ & $31.0(95)$ & $3.97(102)$ & 88.6 \\
\hline
\end{tabular}

\section{Distribution of Vitamin A Alcohol and Ester in Milk}

$1.0 \mathrm{ml}$ of human milk was used. For recovery test, $0.5 \mu \mathrm{g}$ each of vitamin A alcohol and ester, purified as above, was used. Table II shows the results. As can be seen, about 90 per cent of the vitamin in human milk is $\mathrm{A}$ ester and about 10 per cent $\mathrm{A}$ alcohol, in agreement with the results reported by Fujita and Aoyama (1). The level of the vitamin is high in colostrum, decreasing gradually with the days post partum.

\section{Distribution of Vitamin A Alcohol and Ester in the Liver}

Mice were killed by bleeding, the liver extirpated, homogenized with 
TABLE II

Distribution of Vitamin A and Ester in Human Milk

Milk donor : 27 years old, healthy

Parenthesized figures indicate the recoveries of the added vitamin.

\begin{tabular}{cccc}
\hline $\begin{array}{l}\text { Days } \\
\text { post partum }\end{array}$ & \multicolumn{2}{c}{ Vitamin A level in milk } & Ester/total A \\
\cline { 2 - 3 } & Alcohol & Ester & \\
\hline & $\mu g / 100 m l$ & $\mu g / 100 m l$ & per cent \\
1 & $10.2(88)$ & $129.0(100)$ & 92.5 \\
6 & $7.4(90)$ & $69.0(85.5)$ & 90.5 \\
40 & $9.0(97.5)$ & $58.7(110)$ & 86.9 \\
70 & 4.99 & 35.6 & 88 \\
\hline
\end{tabular}

ethanol, centrifuged and $1 \mathrm{ml}$ of the supernatant was used for the main test. For recovery tests, $3 \mu \mathrm{g}$ of A alcohol or $5 \mu \mathrm{g}$ of A ester was added to $1 \mathrm{ml}$ of the supernatant. The results are listed in Table III. About 90 per cent was $\mathrm{A}$ ester and about 10 per cent $\mathrm{A}$ alcohol.

TABLE III

Distribution of Vitamin A Alcohol and Ester in the Liver

Parenthesized figures indicate the recoveries of added vitamin.

\begin{tabular}{ccc}
\multicolumn{2}{c}{ Content of vitamin A in liver } & \\
Alcohol & Ester & Ester/total \\
\hline$\mu g$ & $\mu g$ & per cent \\
$9.0(97.2)$ & $76.5(95)$ & 89.5 \\
\hline
\end{tabular}

4. Changes in Vitamin A Alcohol and Ester in the Serum Following Loading with Vitamin A Alcohol, Ester or $\beta$-Carotene

Samples of A alcohol or ester containing 1, 5, 10, 15 and $30 \mathrm{mg}$, respectively, in $1 \mathrm{ml}$ of olive oil were prepared. The concentration of the vitamin was determined prior to each administration. $\beta$-carotene was given as a suspension containing $4 \mathrm{mg}$ in $4 \mathrm{ml}$ of olive oil.

The experiments were conducted from June 31 till August 8, 1957. The vitamin was given after the interval of $2-4$ days.

Since previous studies $(4,5)$ have shown that the serum A level reaches a maximum about 3 hours after the administration of vitamin $\mathrm{A}$ or $\beta$-carotene, the changes in both forms of the vitamin was determined after 3 hours. As shown in Table IV and Fig. 1, scarcely any increase in A alcohol was observed following administration of either form of the vitamin but there was a marked increase in vitamin $A$ ester. When equivalent amounts were used, the administration of the free form of the vitamin resulted in a slightly greater increase than that of the ester form.

5. Changes in the Free and Ester Forms of the Vitamin in the Milk Follownig Loading with Each Type of the Vitamin

The following experiments were conducted. The subject was a healthy 
TABLE IV

Vitamin A Alcohol and Ester in the Serum Three Hours after Administration of Various Quantities of Vitamin A

Figures indicate the levels of vitamin A in serum ( $\mu \mathrm{g}$ per $100 \mathrm{ml})$.

\begin{tabular}{|c|c|c|c|c|c|c|c|c|c|c|}
\hline \multirow{2}{*}{ Vitamin } & \multirow{2}{*}{ 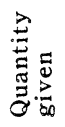 } & \multicolumn{3}{|c|}{ Before loading } & \multicolumn{3}{|c|}{3 hours after loading } & \multicolumn{3}{|c|}{ Increase } \\
\hline & & Ester & Alcohol & Total & Ester & Alcohol & Total & Ester & Alcohol & Total \\
\hline & $m g$ & & & & & & & & & \\
\hline $\begin{array}{l}\text { A alcohol } \\
\text { A ester }\end{array}$ & $\begin{array}{l}1 \\
1\end{array}$ & $\begin{array}{l}7.0 \\
7.7\end{array}$ & & & & & $\begin{array}{l}79.4 \\
83.3\end{array}$ & & $\begin{array}{r}-3.2 \\
3.3\end{array}$ & $\begin{array}{l}19.9 \\
25.1\end{array}$ \\
\hline $\begin{array}{l}\text { A alcohol } \\
\text { A ester }\end{array}$ & $\begin{array}{l}5 \\
5\end{array}$ & $\begin{array}{l}5.7 \\
7.1\end{array}$ & $\begin{array}{l}54.1 \\
50.9\end{array}$ & & $\begin{array}{l}21.0 \\
37.4\end{array}$ & $\begin{array}{l}59.8 \\
54.1\end{array}$ & $\begin{array}{l}80.8 \\
91.5\end{array}$ & & $\begin{array}{l}5.7 \\
3.2\end{array}$ & $\begin{array}{l}21.0 \\
33.5\end{array}$ \\
\hline $\begin{array}{l}\text { A alcohol } \\
\text { A ester }\end{array}$ & $\begin{array}{l}10 \\
10\end{array}$ & $\begin{array}{l}9.3 \\
8.5\end{array}$ & $\begin{array}{l}50.2 \\
51.4\end{array}$ & $\begin{array}{l}59.5 \\
59.9\end{array}$ & $\begin{array}{l}76.9 \\
66.3\end{array}$ & $\begin{array}{l}52.7 \\
55.9\end{array}$ & $\begin{array}{l}129.6 \\
122.2\end{array}$ & $\begin{array}{l}67.6 \\
57.8\end{array}$ & $\begin{array}{l}2.5 \\
4.5\end{array}$ & $\begin{array}{l}70.1 \\
62.3\end{array}$ \\
\hline $\begin{array}{l}\text { A alcohol } \\
\text { A ester }\end{array}$ & $\begin{array}{l}15 \\
15\end{array}$ & $\begin{array}{r}10.3 \\
9.1\end{array}$ & $\begin{array}{l}58.5 \\
47.6\end{array}$ & $\begin{array}{l}68.8 \\
56.7\end{array}$ & $\begin{array}{r}101.5 \\
79.5\end{array}$ & $\begin{array}{l}57.1 \\
52.2\end{array}$ & $\begin{array}{l}158.6 \\
131.8\end{array}$ & $\begin{array}{l}91.2 \\
70.4\end{array}$ & $\begin{array}{l}1.4 \\
4.6\end{array}$ & $\begin{array}{l}89.8 \\
75.1\end{array}$ \\
\hline $\begin{array}{l}\text { A alcohol } \\
\text { A ester }\end{array}$ & $\begin{array}{l}30 \\
30\end{array}$ & $\begin{array}{l}7.8 \\
9.3\end{array}$ & $\begin{array}{l}45.6 \\
49.1\end{array}$ & $\begin{array}{l}53.4 \\
58.4\end{array}$ & $\begin{array}{l}185 \\
135\end{array}$ & $\begin{array}{l}54.6 \\
58.5\end{array}$ & $\begin{array}{l}239.6 \\
193.5\end{array}$ & $\begin{array}{l}177.2 \\
125.7\end{array}$ & $\begin{array}{l}9.0 \\
9.4\end{array}$ & $\begin{array}{l}186.2 \\
135.1\end{array}$ \\
\hline$\beta$-Carotene & 4 & 8.7 & 50.5 & 59.2 & 15.3 & 49.9 & 65.2 & 16.6 & -0.6 & 6.0 \\
\hline
\end{tabular}

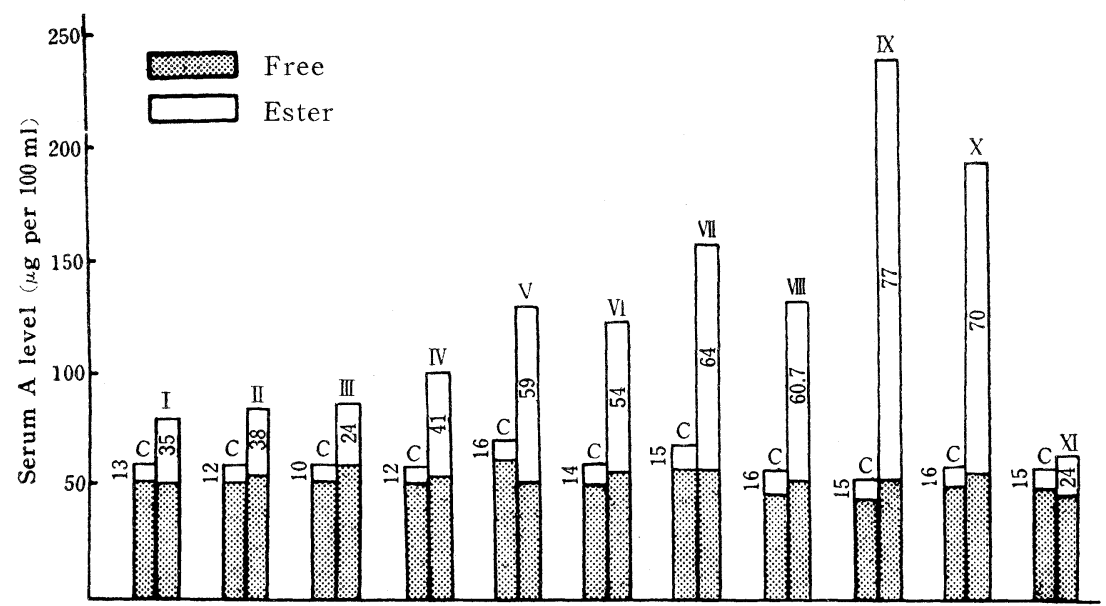

Fig. 1 Vitamin A Alcohol and Ester in the Serum, Before and Three Hours After Oral Administration of Various Vitamin A Preparations

Figures designate the percentage of the ester in serum vitamin A.

$\mathrm{C}$, before administration; I, $1 \mathrm{mg} \mathrm{A}$ alcohol; II, $1 \mathrm{mg}$ A ester; III, $5 \mathrm{mg}$

A alcohol; IV, $5 \mathrm{mg}$ A ester; V, $10 \mathrm{mg}$ A alcohol; VI, $10 \mathrm{mg}$

A ester; VII, $15 \mathrm{mg}$ A alcohol; VIII, $15 \mathrm{mg} \mathrm{A}$ ester; IX, $30 \mathrm{mg}$

A alcohol; X, $30 \mathrm{mg}$ A ester; XI, $4 \mathrm{mg} \beta$-carotene.

female, 26 years old, 2.5 months post partum, $50 \mathrm{~kg}$ in weight. Administration of vitamin preparations was discontinued one week prior to the expriment.

Distribution of Both Types of the Vitamin in the Milk, Congested in the 
Breast - The milk of the congested breast was collected separately 3 times, i.e., initial, middle, and final portions, $27 \mathrm{ml}$ in total, and the distribution of both types of the vitamin in each porion was determined. As shown in Table V, there were no significant difference among the three portions, the ratios free/total being fairly constant.

TABLE V

Distribution of Vitamin A Alcohol and Ester of Samples from Congested Breast

\begin{tabular}{|c|c|c|c|c|}
\hline & & A content & Total A & Ester/total \\
\hline Initial & $\left\{\begin{array}{l}\text { Free } \\
\text { Ester }\end{array}\right.$ & $\begin{array}{c}\mu g \text { per cent } \\
4.4 \\
35.6\end{array}$ & $\begin{array}{c}\mu g \text { per cent } \\
40.0\end{array}$ & $\begin{array}{c}\text { per cent } \\
89\end{array}$ \\
\hline Second & $\left\{\begin{array}{l}\text { Free } \\
\text { Ester }\end{array}\right.$ & $\begin{array}{r}5.0 \\
35.6\end{array}$ & 40.6 & 88 \\
\hline Final & $\left\{\begin{array}{l}\text { Free } \\
\text { Ester }\end{array}\right.$ & $\begin{array}{r}3.7 \\
36.8\end{array}$ & 40.5 & 91 \\
\hline
\end{tabular}

Changes in Both Types of the Vitamin in Milk during the Day ... Milk was collected 3 times, i.e., morning, noon and night, and the contents of the vitamin were measured. Table VI shows that there were no significant differences in the course of the day.

TABLE VI

Changes in Vitamin A Alcohol and Ester in the Milk in a 24 Hour-Period

\begin{tabular}{lcccc} 
& \multicolumn{3}{c}{ Vitamin A level } & \\
& Alcohol & Ester & Total & Ester/total A \\
Morning & 5.1 & $\mu g / 100 \mathrm{ml}$ & & per cent \\
Noon & 5.8 & 37.1 & 42.2 & 88 \\
Night & 3.8 & 35.8 & 41.6 & 86 \\
& & 37.1 & 40.9 & 91 \\
\hline
\end{tabular}

TABLE VII

Changes in Vitamin A Alcohol and Ester in Milk with Time Following a Single Oral Dose of Vitamin A Alcohol and Ester

\begin{tabular}{|c|c|c|c|c|c|c|c|c|}
\hline \multirow{3}{*}{$\begin{array}{l}\text { Time after } \\
\text { loading }\end{array}$} & \multirow{2}{*}{\multicolumn{4}{|c|}{$\begin{array}{l}\text { Loading with } 33.3 \mathrm{mg} \text { of } \\
\text { vitamin A alcohol } \\
\text { Vitamin A level }\end{array}$}} & \multicolumn{4}{|c|}{$\begin{array}{c}\text { Loading with } 33.3 \mathrm{mg} \text { of } \\
\text { vitamin A ester }\end{array}$} \\
\hline & & & & & \multicolumn{3}{|c|}{ Vitamin A level } & \multirow{2}{*}{ Ester/total } \\
\hline & Alcohol & Ester & Total & & Alcohol & Ester & Total & \\
\hline$h r$ & \multicolumn{3}{|c|}{$\mathrm{\mu g} / 100 \mathrm{ml}$} & per cent & \multicolumn{3}{|c|}{$\mu \mathrm{g} / 100 \mathrm{ml}$} & per cent \\
\hline 0 & 3.3 & 38.1 & 41.4 & 92 & 4.2 & 38.2 & 42.4 & 90 \\
\hline 2 & 17.0 & 103 & 120.0 & 86 & 12.1 & 89.8 & 101.9 & 88 \\
\hline 4 & 20.0 & 125 & 145.0 & 86 & 12.7 & 117.0 & 129.7 & 90 \\
\hline 6 & 15.1 & 127.3 & 142.4 & 89 & 15.4 & 111.0 & 126.4 & 88 \\
\hline 8 & 9.8 & 95.2 & 105.0 & 90 & 13.4 & 106.0 & 119.4 & 89 \\
\hline 10 & 13.1 & 87.2 & 100.3 & 87 & 10.0 & 84.5 & 94.5 & 90 \\
\hline 12 & 8.5 & 89.1 & 97.6 & 91 & 8.7 & 75.8 & 84.5 & 90 \\
\hline
\end{tabular}


Changes in Both Types of the Vitamin in Milk Following Oral Administration of Both Types of the Vitamin - As it was found in the above experiments that the contents of both types of the vitamin in milk scarcely change according to the portions of the milk and to the time of the day, the effect of

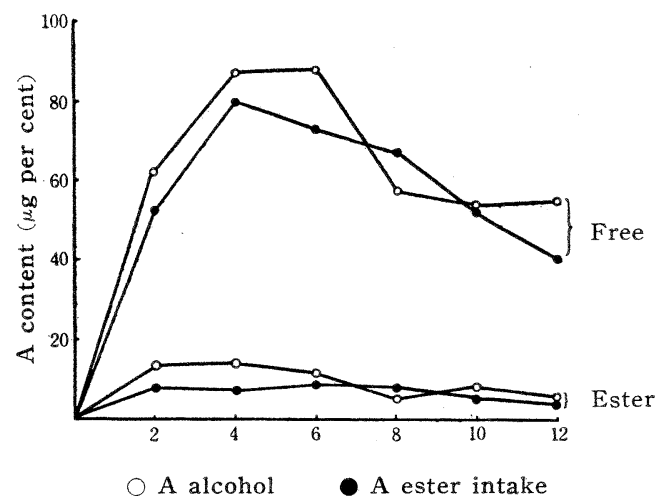

Fia. 2 Changes in Vitamin A Alcohod and Ester in the Milk with Time Following a Single Oral Dose of $33.3 \mathrm{mg}$ of Vitamin A Alcohol or Ester Dissolved in $1 \mathrm{ml}$ Olive Oil. oral administration of free and ester form of the vitamin (33.3 $\mathrm{mg}$ in $1 \mathrm{ml}$ of olive oil) was examined. As can be seen in Table VII and Fig. 2, the ester form of the vitamin in the milk became highest 6 hours after oral administration of A alcohol. Following the administration of A ester, the highest level was reached after 4 hours, gradually decreasing thereafter. Whichever form of the vitamin was administered, there was a marked rise in $A$ ester, whereas no marked increase in $\mathrm{A}$ alcohol took place.

6. Changes in the Free and Ester Forms of the Vitamin in the Liver Following Loading with Both Types of the Vitamin and with $\beta$-Carotene

Pure strain mice were loaded once with $100 \mu \mathrm{g}$ of A alcohol or A ester (dissolved in $0.5 \mathrm{ml}$ of olive oil) or with $2000 \mu \mathrm{g}$ of $\beta$-carotene (dissolved 0.5 $\mathrm{ml}$ of olive oil) and after 15 hours, the levels of the free and ester forms of the vitamin in the liver were determined. In the previous expeiments of the authors $(6,7)$ it was found that the liver A level became highest 15 hours after oral administration of vitamin $A$ or $\beta$-carotene, so the time was selected in the present experiment and the experiment was carried out as before $(6,7)$. As given in Table VIII, there was a marked increase in A ester, whichever form of the vitamin was administered.

TABLE VIII

Changes in Vitamin A Alcohol and Ester in the Liver 15 Hours after a Single Oral Dose of Vitamin A Alcohol or Ester or of $\beta$-Carotene

Figures indicate the average of two mice.

\begin{tabular}{|c|c|c|c|c|c|c|c|}
\hline \multirow{2}{*}{$\begin{array}{l}\text { Form of } \\
\text { vitamin A } \\
\text { given }\end{array}$} & \multirow{2}{*}{$\begin{array}{l}\text { Quantity } \\
\text { given }\end{array}$} & \multicolumn{3}{|c|}{ Content of vitamin A } & \multirow{2}{*}{ Ester/total } & \multicolumn{2}{|c|}{ Increase in vitamin $\mathrm{A}$} \\
\hline & & Alcohol & Ester & Total & & Alcohol & Ester \\
\hline & $m g$ & $\mu g$ & $\mu g$ & $\mu g$ & per cent & $\mu g$ & $\mu g$ \\
\hline 0 & 0 & 4.2 & 60.6 & 64.8 & 94 & 一 & - \\
\hline Ester & 1 & 19.9 & 328.0 & 347.9 & 94 & 15.7 & 267.4 \\
\hline Alcohol & 1 & 26.1 & 297.0 & 323.1 & 92 & 21.9 & 236.4 \\
\hline 0 & 0 & 4.8 & 54.3 & 59.1 & 93 & $\overline{10}$ & - \\
\hline$\beta$-Carotene & 2 & 20.5 & 160.0 & 180.1 & 89 & 15.7 & 105.7 \\
\hline
\end{tabular}




\section{DISCUSSION}

Separation of the free and ester forms of vitamin A has been reported in many papers. The alumina chromatography method has been successfully used by Fujita and Aoyama (8), followed by Muller (9), Reed et al. (10) and Parrish et al. (11). It has been emphasized, however, that it is necessary to conduct a test each time since the adsorbability differs according to the adsorbents (9, 12). Chromatography using bone black has also been reported by Glover et al. (13), but this method is inconvenient, since it requires a large quantity of the sample. Separation by paper chromatography and the determination of the vitamin in the extract of the spot was reported by Datta et al. (14), Kaiser et al. (15) and Suzuki (16), but this method requires further study to be used for quantitative assay. By retest of the experiment of Aoyama (17) using the alumina "Kaken KK2" instead of "BL6" of Japan Aluminium Co., it was found that 67 per cent of the A alcohol added to the serum was recovered as $\Lambda$ ester, whereas 27 per cent was found as $A$ alcohol. The condition, under which KK2 is used as an adsorbent, was studied and the procedure described above was found satisfactory. Almost all the vitamin $\Lambda$ in the blood is present in the serum, whereas little is found in the cellular components, so that for measuring the vitamin A content of the blood only the serum is to be taken into consideration (1).

In the present study, it was found that the majority of the vitamin $A$ in the serum was A alcohol. However, when the vitamin is given orally, mainly A ester was found to rise in the serum, whichever form of the vitamin was administered. Week et al. (18) and Hoch et al. (20) have obtained similar results. The serum $A$ alcohol level appears to remain fairly constant. In other words, the necessary level of A alcohol, an active form of the vitamin, in the serum seems to be regulated to remain constant. That the ester form of the vitamin in the serum rose more after receiving A alcohol than after receiving ester suggests that the ester is first hydrolyzed in the intestines to A alcohol, which in turn is esterified and enters the blood stream, whereas A alcohol, which requires no hydrolysis, is absorbed in larger amounts.

In the milk and liver, on the other hand, the vitamin occurs chiefly in the ester form, and little in the free form. The ester form increased in the blood seems to be transferred to these tissues. The vitamin appearing in the milk after loading with either A alcohol or A ester is mainly in the ester form. The vitamin in the milk reaches a maximum $4-6$ hours after administration, gradually decreaseing thereafter, but even after 12 hours, the level is about twice as high as the preloading level. The finding suggests that the administration of vitamin A preparations to the mother may have a favorable effect for the infant as the vitamin is transferred to the baby. Examination of the relationship between the quantity administered and the amount transferred to the milk, however, as shown in Table VII, revealed that the total vitamin A level in milk was highest 4 hours after administration, amounting to $145 \mu \mathrm{g}$ per $100 \mathrm{ml}$. Subtracting the preloading level, $40 \mu \mathrm{g}$ per $100 \mathrm{ml}$, the increase is calculated to be about $100 \mu \mathrm{g}$ per $100 \mathrm{ml}$. Assum- 
ing $1000 \mathrm{ml}$ as the total quantity of milk produced in 24 hours and that the maximum level is maintained throughout the period, the increase in the vitamin would be only $1 \mathrm{mg}$. Since $33.3 \mathrm{mg}$ of the vitamin had been administered, the quantity secreted in the milk is as small as 3 per cent. From this, it is evident that giving the vitamin directly to the child is far more beneficial than through the mother. Comparing the effect of $\mathrm{A}$ alcohol, $\mathrm{A}$ ester and $\beta$-carotene on the vitamin $A$ level in the liver of mice, $\beta$-carotene was found to be about 40 per cent as effective as vitamin $A$ when given in the same I.U. dosage as reported previously (7).

\section{SUMMARY}

1. A micromethod for fractional determination of vitamin A alcohol and ester was devised and the free and ester forms of the vitamin in serum, milk and liver were determined. Using $1 \mathrm{~N} \mathrm{KOH}$ in 90 per cent ethanol in extraction, the fractional determination could be carried out with practically complete recoveries.

2. With this method it was found that about 90 per cent of vitamin $A$ in human serum was the free form and about 10 per cent the ester form, in agreement with the results obtained previously by the authors.

3. The increase in vitamin $A$ in the serum 3 hours after oral administration of vitamin A alcohol or ester is chiefly in the ester form without significant change in the free form.

4. Contrary to the findings of the serum, about 90 per cent of the vitamin in human milk was in the ester form and about 10 per cent in the free form. The ratio was fairly constant whether the milk is taken from the initial, middle or last portion of the congested breast or taken at different times of the day.

5. The levels of vitamin A and ester in the milk after a single oral administration of $33.3 \mathrm{mg}$ of A alcohol or ester were highest after $4-6$ hours, gradually decreasing thereafter. Whichever form was loaded, it was always the ester that increased significantly, as was the case with serum. There is a slight increase in the free but the rise is insignificant.

6. Of the vitamin $\mathrm{A}$ in the liver, about 90 per cent was the ester form and about 10 per cent the free form. The ratio was about the same as in milk.

7. The vitamin A level in the liver 15 hours after a single oral administration of $1,000 \mu \mathrm{g}$ of $\mathrm{A}$ alcohol or ester or of $2,000 \mu \mathrm{g}$ of $\beta$-carotene in the mouse was found to be increased in the ester form, the rise being 26.7, 33.6 and 5.3 per cent, respectively. The increase in the free form was slight. The rise in vitamin $A$ in the liver after administration of $\beta$-carotene was only about 40 per cent of that following the dose of vitamin A with the same I.U.

\section{ACKNOWLEGMENT}

This work was supported in part by a research grant from the Morinaga-Hoshikai (1958), to which the authors wish to express their grateful appreciation. 


\section{REFERENCES}

1. Fujita, A., and Aoyama, M., Vitamins 5, 47 (1952).

2. Kimura, K., ibid. 11, 362 (1957); Kimura, K., and Fujita, A., J. Vitaminol. 3, 155 (1957).

3. Fujita, A., Vitamin Assay Methods. p. 84, Nankodo, Tokyo (1955).

4. Numata, K., and Kimura, K., Vitamins 15, 16 (1958).

5. Numata, K., and Kimura, K., ibid. 15, 19 (1958).

6. Kimura, K., ibid. 14, 566 (1958).

7. Kimura, K., ibid. 14, 570 (1958).

8. Fujita, A., and Aoyama, M., ibid. 4, 174 (1951).

9. Muller, F., Helv. Chim. Acta 27, 443 (1944).

10. Reed, G., Wise, E. C., Frundt, R. J. L., Ind. Eng. Chem. Anal. Ed. 16, 509 (1945).

11. Parrish, D. B., Wise, G. H., and Hughes, J. S., J. Biol. Chem. 167, 173 (1947).

12. Hoch, H., and Hoch, R., Brit. J. Exptl. Pathol. 27, 1316 (1946).

13. Glover, J., Goodwin, T. W., and Morton, R. A., Biochem. J. 41, 94 (1947).

14. Datta, S. P., Overall, B. G., and Sad-Dunne, M., Nature 164, 673 (1949).

15. Kaiser, E., and Kagan, B. M., Arch. Biochem. Biophys. 63, 118 (1956).

16. Suzuki, T., Vitamins 13, 212 (1957); Suzuki, T., and Sahashi, Y., J. Vitaminol. 3, 288 (1957).

17. Aoyama, M., Kitasato Jikken Igaku 25, 61 (1952).

18. Week, E. F., and Sevigne, F. J., J. Nutrition 40, 563 (1950).

19. Kawaguchi, T., Vitamins 10, 8 (1956).

20. Hoch, H., and Hoch, R., Brit. J. Exptl. Pathol. 27, 316 (1946). 